\title{
Identification of Consumers’ Motives in Buying Organic Luwak Coffee in terms of Agri-Touirism
}

\author{
Yosini Deliana ${ }^{1, *}$, Lucyana Trimo ${ }^{1}$, Sri Fatimah ${ }^{1}$, Mai Fernando $\mathrm{N}^{1}$ and Mohamad \\ Djali $^{2}$
}

${ }^{1}$ Department of Agricultural Social Economics, Faculty of Agriculture, Padjadjaran University, Jatinango- 45363 Indonesia; ${ }^{2}$ Department of Food Industry Technogy- , Padjadjaran University, Jatinangor 45363 Indonesia

Received: February 27, 2021; Revised: June 10, 2021; Accepted: October 16, 2021

\begin{abstract}
.
Cikole luwak (civet) coffee began to be produced in 1990 and is now well-known in about 45 countries. Unfortunately, it is suspected that the civet coffee sold in bulk and retail is just ordinary or plain coffee. The motivation to buy for consumers, the level of consumer interest in civet coffee agrotourism, marketing strategies for loyal consumers to consume civet coffee are the objectives of this study. Questionnaire interviews involving 186 respondents (by means of systematic random sampling) were used as data collection methods in this study. Furthermore, the recorded data were analyzed by Confirmatory Factor Analysis. The results show that the primary factors of Luwak coffee, such as freshness, taste, and aroma, can identify consumer appearance as the dominant factor. The dominant usability factors were habits, leisure; and health; while the dominant promotional factors were website availability, agrotourism, and discounts. The Luwak coffee marketing strategy must be holistic and synergize between government, companies, communities, academics and media.
\end{abstract}

Keywords: Consumer's motive, luwak coffee, external and internal factors , agrotourism, and confirmatory factor analysis

\section{Introduction}

One of the countries that produce the largest coffee in the world is Indonesia which ranks fourth (World Bank, 2015). There are several provinces in Indonesia that produce coffee, one of which is West Java province and Bandung Regency is the largest coffee production center, contributing $70 \%$ of West Java's total coffee production (Coffee Production by Province in Indonesia, 2017-2021). Thus, to maintain coffee production, it is necessary to develop the sustainability of coffee farming which is pioneered by young farmers (Nainggolan, et al., 2020). Cikole Village, Lembang sub-district, was chosen as research area because it has a uniqueness in the market of civet coffee. The uniqueness of this agro-tourism is that visitors can see the whole process from civet coffee cultivation, maintenance, harvest, post-harvest, processing, to marketing. In addition, visitors can also see the behavior of ferrets (Paradoxurus hermaphrodites) when choosing ripe coffee cherries. In addition, the location is also supported by beautiful views so that visitors can relax while drinking civet coffee.

Due to the high price of civet coffee, it is categorized as a luxury product or more specifically the specialty coffee category, although not all luxury products are expensive (depending on the perception of each consumer). According to Wiedmann et al. (2009), the four values of luxury are financial (i.e. price), functional (i.e. usability), individual (i.e. materialism) and social such as conspicuous consumption. A brand is created by adding a core product with distinctive value that distinguishes it from other products (Jobber and Fiona, 2019). Meanwhile, Heine (2021) explains that product appearance, promotion and usability are often considered characteristics of luxury brands. Luwak coffee is one of the luxury coffee products because it has many differences with other coffees including the price which is quite expensive. Consumers tend to feel prestigious every time they consume them, so they are often used as gifts for family, friends or business associates. Those who give and receive civet coffee will get their own satisfaction that cannot be valued in money so that it becomes part of the respect. On the other hand, coffee contains an antioxidant compounds, that showed antibacterial and antibiofilm activities against $\boldsymbol{P}$. aeruginosa and S. Pyogenes (Al Kafaween et al., 2020). The crude methanol extract of $A$. paniculata leaf and its fractions demonstrated considerable antimicrobial and antioxidant properties (Banji et al., 2018). This is the reason why Luwak Coffee has become a specialty coffee.

Consumers who use luxury products or brands can convey certain social and cultural meanings (Becker et al., 2018). Personal and social relationships in society can be described by certain brands and positions. Promotion is one of the determining factors in the success of a marketing program. A product that consumers have never or rarely heard of and believe to be useless will never be purchased by consumers. One form of marketing communication carried out by a company is promotion.

\footnotetext{
*Corresponding author e-mail: y.deliana@gmail.com.
} 
The activities carried out include disseminating information, influencing and being willing to persuade consumers; the target market must always be reminded to be willing to accept, buy, and be loyal to the products offered (Yuliawati et al, 2917). A consumer will usually buy a product based on the appearance, promotion and usability of the product itself. After determining consumer motives, producers will more easily understand consumers and find strategies to improve product quality and expand markets. There is a tendency for consumers to buy Luwak coffee because of taste, unique aroma, good facilities, unique packaging, low price, habit, leisure, and health. The purpose of this study was to determine consumer motivation in buying civet coffee, consumer interest in civet coffee agrotourism, and the marketing strategy that must be chosen. One of the novelties in this research is to identify consumer motives related to luxury products and agro-tourism using factor analysis.

Research that discusses consumer motivation in buying civet coffee is still rarely found (because civet coffee only exists in Indonesia). So far, the research that has been done has only been limited to discussing the efficiency of the civet coffee business (Niken et al, 2018) and the potential and development strategies of civet coffee (Bayunitri, 2017; Pranoto and Rajamin, 2012; Ribek and Rihayana,
2019; Satim and Puput, 2020).

\section{Method}

\subsection{Data}

The primary data recording process was carried out in a cross section through observation and questionnaire instruments based on previous literature reviews. Secondary data were obtained from the Central Bureau of Statistics, Ministry of Agriculture and related agencies. The primary survey was conducted from April - June2020 in Lembang -West Java Province- Indonesia.

\subsection{Sampling}

Lembang was chosen as the research location because it is famous for its civet coffee agrotourism. Systematic random sampling technique was used to collect customer data, by taking 200 samples from a population averaging one thousand consumers per month. The sample was taken from 5 percent of the population, and only 186 were matched with the research variables. Respondents are visitors who come to Luwak coffee for recreation, local tourists and foreign tourists for agro-tourism purposes. The research framework is as follows:

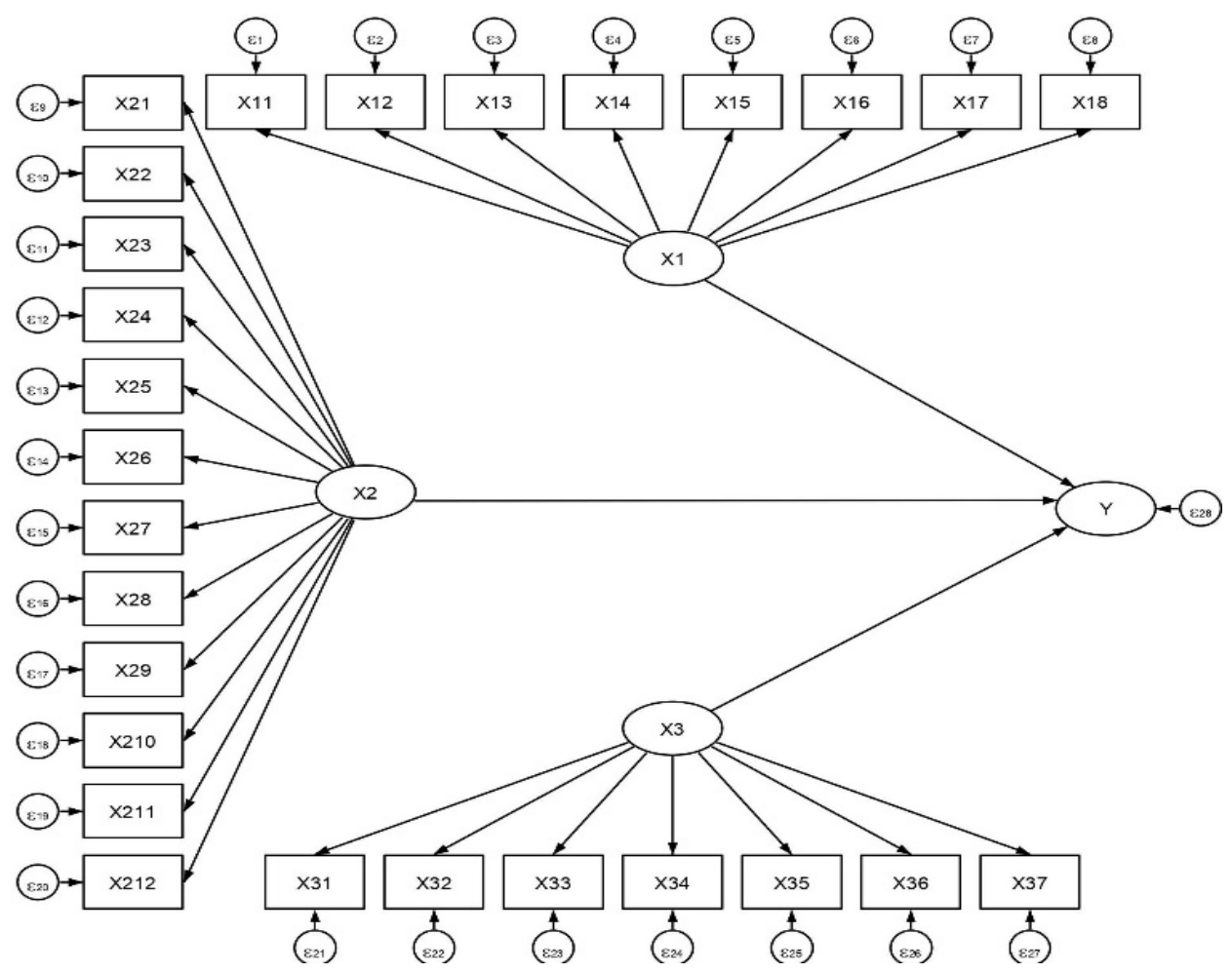

Figure 1. Research Framework

Note: Endogenous Latent Variable

$Y=$ Consumer motivation Exogenous Latent Variables

$X_{1}=$ Appearance ; $X_{2}=$ Promotion; $X_{3}=$ Usability

$\gamma i=$ Path coefficient for $i$ th exogenous latent variables to endogenous latent variable $(i=1,2,3)$; $\lambda i=$ Standardized Loading Factors for $j$ th $k$ th manifest variables/indicators $(i=1,2, \ldots ; j=1,2,3 ; k=1,2, \ldots) ; \varepsilon i=$ Error term for for $j$ th $k$ th manifest variables/indicators $(i=1,2, \ldots ; j=1,2,3$; $k=1,2, \ldots)$

\subsection{Measurement}

There are three factors that influence a brand to be luxurious, including appearance, promotion and product usability. The following table shows the value of the standard loading factor and measurement error for the measurement model on a variable using confirmatory 
factor analysis (CFA). The validity criteria are said to be good if the load factor value of 1.96 is obtained from the $t$ arithmetic value which is greater than $t$ table. Respondents who came to the Luwak coffee area were asked questions by the questioners. Each respondent was given several questions and asked to fill out a form with a choice of a Likert scale, namely the answers strongly agree (5), agree (4), neutral (3) disagree (2) and strongly disagree.

\section{Results}

\subsection{Respondent Profile}

Respondents involved in this study consisted of men (54.84\%) and women (45.16\%). Respondents generally tend to return to buy Kopi Luwak (87.72\%) and the rest do not return $(12.28 \%)$ due to unsuitable taste. The survey results show that those who buy Kopi Luwak are between 20-29 years old, including the millennial generation (Deliana and Rum, 2019). This is in accordance with their work as fresh graduates at the Diploma and Postgraduate levels. What is interesting is that the income of consumers who buy civet coffee is between 5 - 10 million. This is very reasonable since the luwak coffee price is expensive.

Table 1. Respondent Characteristics

\begin{tabular}{|c|c|c|c|c|c|}
\hline Variable & Description & (\%) & Variable & Description & $(\%$ \\
\hline \multirow[t]{4}{*}{ Age (Year) } & $<20$ & 9.68 & Education & $\begin{array}{l}\text { High } \\
\text { School }\end{array}$ & 13 \\
\hline & $20-29$ & 82.26 & & Diploma & 42 \\
\hline & $30-39$ & 4.84 & & Graduate & 37 \\
\hline & $>40$ & 3.23 & & $\begin{array}{l}\text { Post } \\
\text { Graduate }\end{array}$ & 6.5 \\
\hline \multirow[t]{4}{*}{ Occupation } & $\begin{array}{l}\text { Private } \\
\text { sector }\end{array}$ & 17.74 & $\begin{array}{l}\text { Income } \\
\text { (IDR/month) }\end{array}$ & $<5$ million & 30 \\
\hline & Entrepreneur & 27.42 & & 5- 10 & 58 \\
\hline & $\begin{array}{l}\text { Fresh } \\
\text { graduate }\end{array}$ & 33.87 & & $11-15$ & 10 \\
\hline & Others & 22.57 & & $>15$ & 0.5 \\
\hline
\end{tabular}

Usually, the X-Generation (39 - 54 years) and Baby Boomer Generation ( $>55$ years) visit the Luwak coffee place just to see the beautiful scenery and recreation. This is because those generations are generally already working, have a large income, and want to enjoy life. Meanwhile, millennials (23-38 years old), especially fresh graduates, tend to visit to enjoy the sensation of drinking Luwak coffee and edu-entertainment.

A Luwak coffee has a special characteristic, namely the natural fermentation process that distinguishes the taste/aroma from other coffees. The fermentation process becomes the selling point of Luwak coffee; besides, the volume of Luwak coffee production is not much due to the limited number of captive civets. A civet produces 600 grams/day or about $12 \mathrm{~kg} / \mathrm{head} / \mathrm{month}$ (Satim and Pupung, 2020). However, for consumers who like to drink coffee, price is not an issue but quality must be reliable (Wróblewsk et al., 2017; Wann et al., 2018).

\subsection{The Consumer's Motive in Buying Luxury Brand of Luwak Coffee}

Internal and external factors are indicated as consumer preferences $(\mathrm{Y})$ which are depicted for identification of luwak coffee consumers. Appearance $\left(\mathrm{X}_{1}\right)$ and usefulness $\left(\mathrm{X}_{3}\right)$ are internal factors, while promotion $\left(\mathrm{X}_{2}\right)$ is external factor. The factors such as taste $\left(\mathrm{X}_{11}\right)$, aroma $\left(\mathrm{X}_{12}\right)$, and freshness $\left(X_{14}\right)$ are the dominant factors of appearance. The dominant factor usability includes Habit $\left(\mathrm{X}_{33}\right)$, leisure $\left(\mathrm{X}_{34}\right)$ and Health $\left(\mathrm{X}_{\cdot 35}\right)$. The dominant factor promotion is website available $\left(\mathrm{X}_{25}\right)$, agrotourism $\left(\mathrm{X}_{26}\right)$ and discount $\left(\mathrm{X}_{30}\right)$.

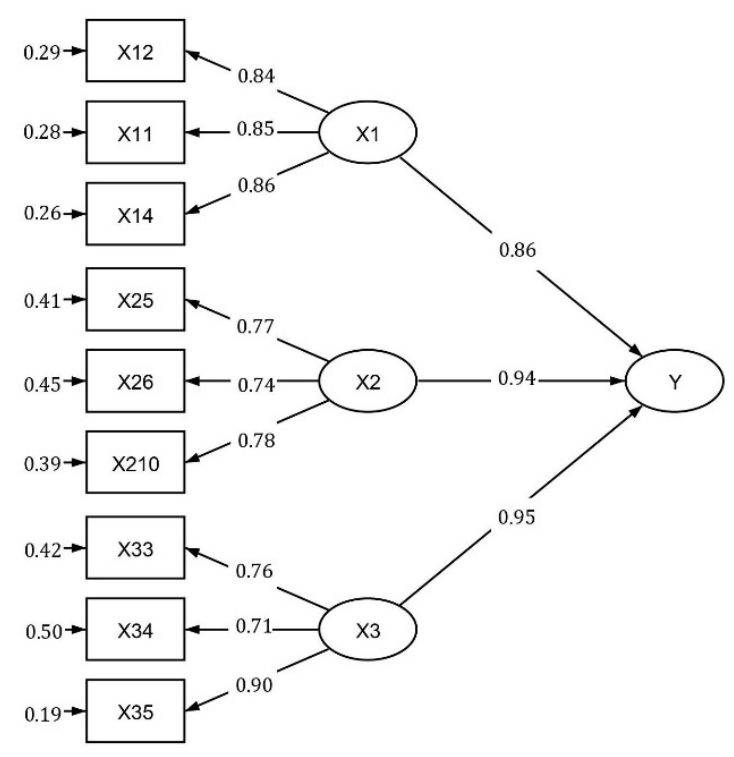

Figure 2. Dominant Factors Influence Consumer Motivation in 37\&uying Luwak Coffee

6.5 Note: $Y=$ Consumer motivation, $X_{1}=$ Appearance, $X_{11}=$ Taste, $X_{12}=$ Aroma, $\quad X_{14}=$ Freshness, $X_{2}=$ Promotion, $X_{25}=$

Website available, $X_{26}=$ Agrotourism , $X_{210}=$ Discount , 58. $X_{3}=$ Usability , $X_{33}=$ Habit , $X_{34}=$ Leisure , $X_{35}=$ Health

10.4 On consumer expertise and sensory skills, preference for different intrinsic qualities is dependent (Quintao et al, $0.5017)$. The taste, aroma, and freshness of this distinctive Luwak coffee is the main attraction for the proliferation of coffee shops. Several factors can affect the success of a coffee shop business, including taste, facilities and speed of service, and others (Humiras et al , 2017). If the assumption of linearity is not modeled, internal factors can be used as predictors of consumer loyalty (Deliana and Rum., 2017). Coffee users expect more satisfaction in their social experience than to pursue a taste and enjoy the service of coffee. To meet the punctuality of drinking coffee, the take-out service can meet the demands of the community, besides that there are also many social coffee drinking places that are made in several areas (Zhengyu et al., 2019).

Some consumers buy coffee for health reasons and concerns for the environment. Consumers have high knowledge, but buying environmentally friendly products is not necessarily good behavior (Deliana et al., 2017). This is the case between consumer subjective norms and purchase intentions, even though consumers believe the product is environmentally friendly, consumers do not necessarily buy (Phuah et al., 2018). Even so, prices remain a consideration for consumers in buying green products (Balathandayutham and Anandanatarajan., 2019; Hashim et al., 2019). If their customers are satisfied 
and it meets their expectations, they are willing to pay more. Consumers' wants and expectations include communications, products, and marketing promotions that appeal to the heart, attract all senses, stimulate thoughts, and make it into their lifestyle (Kim et al., 2018; Rather, 2020).

\subsection{The consumer interest in Luwak coffee agro- tourism}

This research revealed that agro-tourism is one consumer motivation to buy Luwak coffee in CikoleLembang. Consumer interest in Luwak coffee was calculated by respondent (n) divided total respondent (186 person).39.78 \% consumer who very interested in agrotourism, $31.11 \%$ respondents interest, $16.13 \%$ respondent ordinary, $11.29 \%$ less interested, and $2.68 \%$ respondent not very interested. While the reason respondents visited the location of Luwak coffee in Cikole Lembang are $9 \%$ enjoying the sensation of drinking Luwak coffee, $34 \%$ enjoy the beautiful view of the location, $28 \%$ for leisure, $17 \%$ buying Luwak coffee for souvenirs and $12 \%$ for edu-entertainment to know how the initial process of ripe coffee beans eaten by the civet till the coffee ready for consumption. For the millennial generation this experience is very interesting and memorable. Thus, in general, respondents are interested in visiting Luwak coffee just to see the natural scenery there, not to enjoy the beverage which is luwak coffee. Respondents normally buy the coffee only as a gift for family and friends.

\section{Discussions}

From the research model, it is stated that the most influential factors on consumer motivation in purchasing luwak coffee were freshness, taste, aroma, discount, website availability, agrotourism, health, habit, and leisure. The experience of drinking coffee involves factors that are important to create a multisensory effect. This can be used to enhance the coffee drinking experience by considering the consumer's sensory properties (Fabiana and Charles, 2019), including the freshness, taste and aroma. Drinking coffee while looking at the beautiful scenery is a memorable experience for visitors. This is related to experiential marketing, namely sensory experience (sense), affective experience (feel), creative cognitive experience (think), physical experience, behavior and lifestyle (act), and the experience of social identity resulting from relating to a reference group, culture or relate (Etkin and Sela, 2016; Liu and Ping, 2017). Memorable place is a value created by agrorourism that makes visitors satisfied and ultimately loyal (Lewis, 2015; Lin, 2019). This experience is a novelty feeling, fun and aesthetic perception after consumers' consumption (Katherine and Peter, 2016).

The research results by Rauniyar et al. (2020) on coffee agrotourism is the importance of researching the use of information and communication technology. Based on the research, it was revealed that wi-fi facilities are important for visitors. Nowadays, consuming hot coffee outside the home has become a lifestyle (Kanjanakom and Lee, 2017); of course with the availability of wi-fi provided by coffee shops, it has attracted many consumers (Wu., 2017). Free Wi- Fi, low price and the attractiveness of Luwak coffee agrotourism become typical visitor expectations. The research also revealed that the motivation of visitors to choose Luwak coffee was for reasons of health, habit, leisure, eventually becoming a habit and a lifestyle. This is in line with the results of research by Susanty and Kenny (2015) and Samoggia et al (2018).

Agritourism is visiting an active agricultural holding (a farm or ranch) for leisure, recreation or even educational programs (Gil Arroyo, Barbieri, \& Rozier Rich, 2013; McGehee \& Kim, 2004; Tew \& Barbieri, 2012). There are several issues and challenges of agritourism, small size of the farm lands, lack of necessary skills, poor level of product development, and poor publicity and promotion (Putra et al , 2019). The marketing strategy of luwak coffee must be holistic and synergize between government, companies, communities, academician and media. The undevepelopment of Agrotourism normally caused by the poor government and planning, (Anbalagan and Brebt, 2021). Hence the government should supervise the monopoly of tour operators, infrastructure development towards Luwak coffee agritourism, environmental pollution, provide supervision on the cleanliness and comfort of visitors. The government should also create a new-style tourism pattern different from traditional recreational activities and combining ecological conservation, environmental education, and cultural experience (Mike., 2019; Sawe., 2019).

For developing the marketing of civet coffee, a company must adapt the Starbucks marketing strategy by involving customers in all its activities (value co creation). That is, they should develop new products and product differentiation based on customers' expectations and suggestions. The step starts with the customer writing down what requests, suggestions, and complaints have been felt so far (Asli Qztopcu., 2017). The strategy that must be considered, the promise strategy, must be right on target and must be honest. In sales promotions carried out by service providers, consumers actually know this information, but are reluctant to participate. So, then, to stay afloat and compete with other brands, sales promotions must be made carefully and transparently so as to make consumers interested and have an influence on purchases. In addition, this can create a sense of trust in consumers (Eleboda., 2017).

In terms of the local community, they must be able to introduce the local culture, art and unique products that are related to coffee. The role of academics is to empower and enlighten the community in terms of increasing the added value of civet coffee. Meanwhile, the mass media plays a role in promoting civet coffee business opportunities so that many millennial farmers become interested. Entrepreneurship in the field of agro-tourism can be developed, and this can create added value for the local community (Stanovčić et al., 2018).

\section{Conclusion}

The results showed that the identification of luwak coffee consumers can be seen from the appearance, promotion, and usability. Freshness, taste and aroma are the main factors of appearance. Discounts, website availability and agro-tourism are the dominant factors in 
promotion. Health, habits and leisure are the dominant factors for the usefulness of civet coffee products. Discounts, accessibility and agro-tourism are the dominant factors in promotion. Health, habits, and leisure are the dominant factors in the use of civet coffee products. The reason most consumers visit the luwak coffee location is just to see the surrounding natural scenery, not to enjoy the drink of luwak coffee. The luwak coffee marketing strategy must be holistic and synergize between government, companies, communities, academics and media.

\section{Acknowledgement}

We would like to thank Padjadjaran University for the research funds provided in the Academic Leadership Program 2020 with contract number 1427 / UN6.3.1/ LT / 2020. Thank you for the anonymous reviewers who provided helpful suggestions.

\section{References}

Anbalagan, K., \& Lovelock, B. 2014. The potential for coffee tourism development in Rwanda-Neither black nor white. Tour.Hosp. Res., 14, 81-96

Al-kafaween Mohammad A , Abu Bakar M. Hilmi , Norzawani Jaffar, Hamid A. N. Al-Jamal, Mohd K. Zahri and Fatima I. Jibril. 2020. Antibacterial and Antibiofilm activities of Malaysian Trigona honey against Pseudomonas aeruginosa ATCC 10145 and Streptococcus pyogenes ATCC 19615. Jordan J Biol Sci., 13(1): $69-76$

Asli Q. 2017. Evaluation of competitive strategies of coffee retailing in aspect of market economy. Int. J. Bus. Manag., 5(2): 246- 267.

Balathandayutham P and Anandanatarajan K. 2019. Price and green attitude towards environmental friendly product in Chidambaram. Rev. Res., 1 :226-231

Becker Kip, Jung Wan Lee and Helena M. Nobre. 2018. The concept of luxury brands and the relationship between consumer and luxury brands. J. Asian Finance Econ. Bus. 51-63

Bayunitri, B. I. 2017. Customer perceptions of product Luwak Coffee based on marketing mix elements perspective (Customer Survey In Bandung). International Conference on Organizational Innovation (ICOI 2017). 194-198. Atlantis Press

Banji Adaramola , Benjamin Goodluck , Otuneme Oluchi and Fapohunda Stephen . 2018. Antimicrobial and Antioxidant Activities of Crude Methanol Extract and Fractions of Andrographis paniculata leaf (Family: Acanthaceae) (Burm. f.) Wall. Ex Nees. Jordan J Biol Sci., 11(1) : 23 - 30.

Central Bureau of Statistics Coffee. 2018. Production by Province in Indonesia, 2017-2021

Deliana Y and Rum I A. 2017.Understanding consumer loyalty using Neural Network. Pol. J. Manag Stud.16(2):17512.

Deliana, Y and Rum I A. 2019. How does perception on green environmrnt across generations affect consumer behavior? A neural network process. Int J Consum Stud., 10 (111): 1-10.

Deliana, Y, Endah D, Engkus K and Tuhpawana P S. 2017. The perception of green marketing (A Case in Jatinnagor, West Java Province, Indonesia). Int. J. Econ., 14: 201- 215.

Eleboda S S. 2017. Sales promotion as a strategy in service marketing exploring the believability dilemma and consumer purchase decision. J. Mark. Res., 3(2): 8-15.
Etkin J, Sela A. 2016. How experience variety shapes postpurchase product Evaluation. J. Mark. Res., 53(1): 77-90.

Fabiana M C and Charles S. 2019. Cup colour influences consumers expectations and experience on tasting specialty coffee. Food Qual. Prefer., 75: 157-169.

Gil Arroyo, C., Barbieri, C., \& Rozier Rich, S. 2013. Defining agritourism: A comparative study of stakeholders' perceptions in Missouri and North Carolina. Tour. Manag., 37:39-47.

Hashim M, Baig S A, Abrar M, Afzal A and Mohsin, M. 2019. Effects of Green Marketing on Green Purchase Intentions. Dialogue., 14(2):1819-6462.

Heine Klaus. 2012. The Concept of Luxuary, second ed. Emlyon Business School, France

Jobber David and Fiona Ellis Chad Wick. 2019. The Principles and Practice of Marketing, ninth ed. Mc. Graw Hill Education. London

Kanjanakom A and Lee J. 2017. Examining emotions and comparing the essense profile and the coffee drinking experience in coffee drinkers in the natural environment. Food Qual. Prefer., 56:69-79.

Katherine NL, Peter CV. 2016. Understanding customer experience throughout the customer journey. J. Mark., 80(6): 6996.

Lewis S. 2015. Qualitative inquiry and research design: Choosing among five approaches. Health Promot. Pract., 16(4): 473-475.

Liu, Yajuan \& Ping Gui. 2017. An analysis of the problems and countermeasures in the Application of Experiential Marketing - A Case Study of Starbucks. Proceedings of the seventh International Conference on Education, Management, Information and Mechanical Engineering (EMIM 2017), Hainan Tropical Ocean University, Shenyang, China.

Mbango, Phineas . 2019. The role of perceived value in promoting customer satisfaction: Antecedents and consequences. Cogent Soc. Sci., (pp. 1-16).

McGehee, N. G. 2007. An agritourism systems model: A weberian perspective. J. Sustain. Tour., 15(2) :111-124.

Mike T Y L . 2019. Effects of experiential marketing on experience value and customer satisfaction in ecotourism. Ekoloji Dergisi., 107: 3151-3156.

Nainggolan, MF and Nugraha, A Turnip. 2020. Empowering of young farmer for Arabica Coffee Farming Business in Simalungun. IOP Conference Series: Environ. Earth Sci., 466 (012034): 1-9.

Phuah K T, Mun W O, Sukjeet K S and Umi K K . 2018. Green attitude and purchase intention towards environmental friendly product. Journal of Emerging Economies \& Islamic Research (JEEIR). 6 (1): 17-25.

Putra A, Amalia F R and Utami S W. 2019. Community based Agro-Tourism development strategy for Sumber Arum Village, Songgon, Banyuwangi. Int. j. appl. sci. tourism events., 3(1): 6880 .

Pratono, A. H., \& Radjamin, I. P. 2012. Kopy Luwak: a conservation strategy for global market. Emerald Emerging Markets Case Studies.

Z , Mei-Ling L , Hui L , Min L and Jian-Guo Zhou. 2015. Coffee consumption and risk of endometrial cancer a doseresponse metaanalysis of prospective cohort studies. Sci. Rep., 5: 13410.

Quintão R T, Brito E P Z and Belk R W. 2017. The taste transformation ritual in the specialty coffee market. Rev. Adm. Empresas., 57(5): 483-494. 
Rather R A. 2020. Customer experience and engagement in tourism destinations: the experiential marketing perspective. J. Travel Tour. Mark., 37(1):15-32.

Rauniyar, S., Awasthi, M. K., Kapoor, S., \& Mishra, A. K. 2021. Agritourism: structured literature review and bibliometric analysis. Tour. Recreat. Res., 46(1):52-70.

Ribek, P. K., \& Rihayana, I. G. (2019). Innovation as a strategy of Agrowical competition advantage in improving marketing performance of Luwak Coffee products in Gianyar Bali. Int. J. Appl. Business Int. Manag., 4(2): 41-48.

Satim Hamid and Pupung Purnamasari. 2020. Analysis marketing strategy of Coffee Luwak Cikole A Case Study. Int. J. Entrepreneurship Innov., 2(4):205-211.

Sawe B J. 2019. Influence of cultural heritage dimension on potential Agro-Tourism development in Nandi County, Kenya. African J. Sci. Technol. Innov. Dev., 5(2):141-154.

Stanovčić T, Peković S, Vukčević J and Perović D. 2018. Going entrepreneurial: Agro-tourism and rural development in Northern Montenegro. Bus. Syst. Res., 9(1):107-117.

Susanty, A and Kenny E. 2015. The relationship between brand equity, customer satisfaction, and brand loyalty on coffee shop: Study of Excelso and Starbucks. AMJ., 14:27.

World Bank. 2015. Toward a more competitive dynamic value chain for Indonesian Coffee. World Bank Working Paper No. 7.
Tew, C., \& Barbieri, C. (2012). The perceived benefits of agritourism: The provider's perspective. Tour. Manag., 33(1), 215-224. https://doi.org/10.1016/j.tourman.2011.02.005

Wann, Jong W, Kao, C Y and Yang Y C. 2018. Consumer preferences of locally Grown Specialty Crop. The Case of Taiwan Coffee Sustainability., 10 (7): 2396

Wiedmann, K. P., Hennigs, N., \& Siebels, A. 2009. Value-based segmentation of luxury consumption behavior. Psychol Mar., 26(7), 625-651

Wu H C. 2017. What drives experiential loyalty? A case study of starbucks coffee chain in Taiwan. Br. Food J., 119 (3): 1-51

Wróblewski $Ł$ and Mokrysz S. 2017. Consumer preferences for coffee types and coffee bean brands available on the Polish market. J. adv. humanit., 3(10): 36352-36362.

Yuliawati, A., Budiman, A. and Hadian, M. 2017. Geoheritage and brand awareness of Batur Geopark through e-promotion. Increasing Management Relevance and Competitiveness. Proceedings of the Second Global Conference on Business, Management and Entrepreneurship (GCBME 2017). Bandung Institute Technology, West Java, Indonesia

Zhengyu Wang, Meiyu Zhou and Xiangyu Liu. 2019. Research on the effectiveness of service design based on the Quantitative Method of Kansei Engineering. Taking the LANNA coffee service process as an example. IOP Conf. Ser.: Mater. Sci. Eng. 616012035 . DOI : 10.1088/1757-899X/616/1/012035 
Table2. Parameter estimates the Loading Factor and $t_{\text {value }}$ Model measurements on variable Brand

\begin{tabular}{|c|c|c|c|c|c|}
\hline \multicolumn{2}{|c|}{ Variabel } & $\lambda$ & t hitung & Error & Explanation \\
\hline \multicolumn{6}{|c|}{ Appearance $\left(X_{1}\right)$} \\
\hline $\mathrm{X}_{11}$ & There is a sweet taste in coffee & 0,85 & - & 0,28 & Valid \\
\hline $\mathrm{X}_{12}$ & Aroma & 0,84 & 14,06 & 0,29 & Valid \\
\hline $\mathrm{X}_{13}$ & Brand of coffee & 0,50 & 7,02 & 0,75 & Valid \\
\hline $\mathrm{X}_{14}$ & Freshness & 0,86 & 14,60 & 0,26 & Valid \\
\hline $\mathrm{X}_{15}$ & Color & 0,55 & 7,91 & 0,70 & Valid \\
\hline $\mathrm{X}_{16}$ & Variety of product & 0,77 & 12,41 & 0,41 & Valid \\
\hline $\mathrm{X}_{17}$ & Price suitability & $-0,1$ & $-1,25$ & 0,99 & Not Valid \\
\hline $\mathrm{X}_{18}$ & Brand trust & 0,47 & 6,57 & 0,78 & Valid \\
\hline \multicolumn{6}{|c|}{ Promotion (X2) } \\
\hline $\mathrm{X}_{21}$ & Unique Packaging & 0,28 & - & 0,92 & Valid \\
\hline $\mathrm{X}_{22}$ & Packaging material & 0,49 & 3,34 & 0,76 & Valid \\
\hline $\mathrm{X}_{23}$ & Tourist Guidance & 0,42 & 3,18 & 0,82 & Valid \\
\hline $\mathrm{X}_{24}$ & Facility & 0,55 & 3,44 & 0,70 & Valid \\
\hline $\mathrm{X}_{25}$ & Website available & 0,77 & 3,65 & 0,41 & Valid \\
\hline $\mathrm{X}_{26}$ & Agrotourism & 0,74 & 3,62 & 0,45 & Valid \\
\hline $\mathrm{X}_{27}$ & Free Delivery & 0,44 & 3,24 & 0,81 & Valid \\
\hline $\mathrm{X}_{28}$ & Country of Labeling & 0,08 & 1,04 & 0,99 & Not Valid \\
\hline $\mathrm{X}_{29}$ & Green packaging & 0,65 & 3,56 & 0,58 & Valid \\
\hline $\mathrm{X}_{210}$ & discount & 0,78 & 3,65 & 0,39 & Valid \\
\hline $\mathrm{X}_{211}$ & Welcome drink & 0,68 & 3,58 & 0,54 & Valid \\
\hline $\mathrm{X}_{212}$ & Product knowledge & 0,55 & 3,44 & 0,70 & Valid \\
\hline \multicolumn{6}{|c|}{ Usability (X3) } \\
\hline $\mathrm{X}_{31}$ & $\begin{array}{l}\text { Concern of enviromentaly } \\
\text { friendly }\end{array}$ & 0,62 & - & 0,62 & Valid \\
\hline $\mathrm{X}_{32}$ & Prestige & 0,69 & 7,96 & 0,52 & Valid \\
\hline $\mathrm{X}_{33}$ & Habit & 0,76 & 8,57 & 0,42 & Valid \\
\hline $\mathrm{X}_{34}$ & Leisure & 0,71 & 8,12 & 0,50 & Valid \\
\hline $\mathrm{X}_{35}$ & Health & 0,90 & 9,6 & 0,19 & Valid \\
\hline $\mathrm{X}_{36}$ & $\begin{array}{l}\text { Experience in watching coffee } \\
\text { luwak was produced }\end{array}$ & 0,61 & 7,21 & 0,63 & Valid \\
\hline $\mathrm{X}_{37}$ & Sensation & 0,58 & 6,91 & 0,66 & Valid \\
\hline
\end{tabular}

